\title{
Carbon and Nutrient Inputs by Litterfall into Three Chestnut High Forest Stands in Northern Portugal
}

\author{
M.S. Patrício, E. Pereira, L.F. Nunes and M.L. Monteiro \\ Centro de Investigação de Montanha - CIMO \\ Bragança Polytechnic Institute, ESAB \\ Quinta $\mathrm{S}^{\text {ta }}$. Apolónia, Apartado 1172 \\ 5301-855 Bragança \\ Portugal
}

Keywords: Castanea sativa Mill., litterfall biomass, nutrient concentrations

\begin{abstract}
Litter fall in three high forest chestnut stands, located in different soil types, in Bornes, Marão and Padrela, northern Portugal, with 45, 63 and 65 years old, respectively, was collected during two years in December by a $0.5 \times 0.5 \mathrm{~m}$ square method. Four kinds of samples were collected in this study - (1) leaf litter composed by vegetal materials resulting from the litter fall of the year; (2) leaf litter composed by a mixture of vegetal materials in different decomposition stages; (3) soil from $0-5$ cm depth and (4) soil from 5-10 cm depth. Litter of the year was separated into the fractions leaves, branches, fruits and burs. All fractions were dried at $70^{\circ} \mathrm{C}$, weighted and concentrations of $\mathrm{N}, \mathrm{P}, \mathrm{K}, \mathrm{Ca}, \mathrm{Mg}, \mathrm{S}, \mathrm{B}$ and $\mathrm{C}$ were measured. The total amount of litter in the three chestnut stands was 8.3, 7.7 and 12.4 $\mathrm{Mg} \mathrm{ha}^{-1} \mathrm{year}^{-1}$, respectively. Leaves are the main constituents of the total litter with 54,62 and 50 $\%$, respectively. The proportions of the other litter fractions range from 10 to $19 \%$ for the burs, 20 to $32 \%$ for the branches and 4 to $10 \%$ for the fruits. Regarding the amounts of the nutrients in the litter fractions, in general, leaves are rich in $\mathrm{N}>\mathrm{Ca}>\mathrm{Mg}>\mathrm{K}>\mathrm{P}>\mathrm{S}$; fruits are rich in $\mathrm{N}>\mathrm{K}>\mathrm{Mg}>\mathrm{Ca}>\mathrm{P}>\mathrm{S}$. In the branches, $\mathrm{N}$ and $\mathrm{Ca}$ amounts dominate clearly and the burs are rich in $N$ and $K$. The return of nutrients by litterfall is relevant: it ranges from 57-142 $\mathrm{kg} \mathrm{ha}^{-1}$ year $^{-1}$ for $\mathrm{N}, 5-10 \mathrm{~kg} \mathrm{ha}^{-1}$ year $^{-1}$ for $\mathrm{P}, 13-45 \mathrm{~kg} \mathrm{ha}^{-1}$ year $^{-1}$ for $\mathrm{K}, 28-65 \mathrm{~kg} \mathrm{ha}^{-1}$ year $^{-1}$ for Ca, 18-34 kg ha year $^{-1}$ for $\mathrm{Mg}$, 2-8 kg ha year $^{-1}$ for $\mathrm{S}$ and 87-117 $\mathrm{g} \mathrm{ha}^{-1}$ year $^{-1}$ for $\mathrm{B}$. Carbon in the litterfall ranges between 4 and $6.3 \mathrm{Mg} \mathrm{ha}^{-1}$ year $^{-1}$. It was verified that the biomass nutrients concentrations are strongly dependent on the soil as has been reported by other authors.
\end{abstract}

\section{INTRODUCTION}

Annual return of bioelements to the soil through litter fall is one of the most important renewal factors of forest ecosystem sustainability. Organic residue, accumulated in the soil surface, is responsible for humus formation, which represents a provisional accumulation of nutrients that are gradually released into the soil.

Although sweet chestnut (Castanea sativa Mill.) grows on a wide variety of soils, optimal conditions for this species are deep, moderately fertile and acid soils, $\mathrm{pH} 4.0-4.5$ (Kerr and Evans, 1993). Others authors consider optimum $\mathrm{pH}$ around 5.5 (Bourgeois et al., 2004). In Portugal, chestnut stands grow in soil types as Regosols, Cambisols and Leptosols. In poor nutrient soils the ecosystem productivity is highly influenced by the efficiency of nutrient cycling (Duvigneaud, 1984). In this context, litter is an important reservoir of nutrients to the site productivity and sustainability. In accordance with Kavvadias et al. (2001), growth and productivity of forest ecosystems depends mainly on the amount, nature and decomposition rate of litter. The role of litter decomposition in nutrient cycling is very important in every forest type but it becomes still more important in Mediterranean forest ecosystems due to the action of wild fires (Kavvadias et al., 2001). The lack of information on the litter decomposition dynamics of chestnut stands is a gap that will be considered at further researches. In this particular study we quantify litter fall, litter accumulation on soil and also nutrients and carbon sequestration both in 
two fractions of litter and in the first ten centimetres of soil in three old high forest chestnut stands, located in Northern Portugal. The objective of this study was to quantify and compare the litter biomass produced in the three sites and to evaluate its richness in nutrients and carbon contents that were progressively returned to the soil.

\section{MATERIALS AND METHODS}

This study is based on litter fall information collected in the three old chestnut high forest stands located in Northern Portugal: Bornes $\left(41^{\circ} 29^{\prime} 42^{\prime \prime} \mathrm{N}, 6^{\circ} 55^{\prime} 12^{\prime \prime} \mathrm{W}\right.$ and $800 \mathrm{~m}$ above the sea level), Marão (41 ${ }^{\circ} 14^{\prime} 46^{\prime \prime} \mathrm{N}, 7^{\circ} 55^{\prime} 04^{\prime \prime} \mathrm{W}$ and $900 \mathrm{~m}$ above the sea level) and Padrela (41 31 ' $47^{\prime \prime} \mathrm{N}, 7^{\circ} 35^{\prime} 22^{\prime \prime} \mathrm{W}$ and $850 \mathrm{~m}$ above the sea level) with 45 , 63 and 65 years old, respectively. The total annual rainfall is $1009 \mathrm{~mm}$ in Bornes, 2505 $\mathrm{mm}$ in Marão and $1132 \mathrm{~mm}$ in Padrela. The mean annual temperature is $11.9^{\circ} \mathrm{C}, 13.4^{\circ} \mathrm{C}$ and $12.5^{\circ} \mathrm{C}$, following the same order and maximum and minimum temperatures are 37.2 and $-11.4^{\circ} \mathrm{C}$ in Bornes, 39.7 and $-6.8^{\circ} \mathrm{C}$ in Marão and 37.5 and $-7.4^{\circ} \mathrm{C}$ in Padrela. Tree densities are 1227 trees ha ${ }^{-1}$ in Bornes, 485 trees ha ${ }^{-1}$ and 259 trees ha $^{-1}$ in Marão and Padrela, respectively. Prevailing soil types in the stands are Dystric Cambisols in Bornes, Umbric Regosols in Marão and Dystric Regosols in Padrela according World Reference Base for Soil (FAO, 1998). The 0-10 cm stand soil characteristics are given in Table 1. In Portugal, the chestnut area is mainly composed by orchards, coppices and young stands, while the high forest chestnut area of old stands is reduced. In the study area, where the chestnut has got its largest distribution, the stands occupy an area just about 8 hectares.

Litter was collected in December, after the litter fall, during two successive years, by using a $0.5 \times 0.5 \mathrm{~m}$ square method sampling. In each study place 18 randomly sampling units were considered. In each sampling unit four kinds of samples were collected - (1) leaf litter composed by vegetal materials resulting from the litter fall of the year (L); (2) leaf litter composed by a mixture of vegetal materials in different decomposition stages $(\mathrm{F}+\mathrm{H})$; (3) soil from $0-5 \mathrm{~cm}$ depth and (4) soil from 5-10 cm depth.

Litter of the year, in each sample, was separated into the fractions: leaves, branches, fruits and burs. Fractions were oven-dried to a constant weight at $70^{\circ} \mathrm{C}$, weighted and milled. Ground material was analysed for $\mathrm{N}, \mathrm{P}, \mathrm{K}, \mathrm{Ca}, \mathrm{Mg}, \mathrm{S}, \mathrm{B}$ and $\mathrm{C}$, by applying specific analytical methods. N, P and $\mathrm{K}$ were extracted by sulphuric digestion, $\mathrm{Ca}, \mathrm{Mg}$ and $\mathrm{S}$ by nitric-perchloric digestion and $\mathrm{B}$, by means of dry incineration method. The analytical determinations of N, P and B in the extract were obtained by atomic absorption spectrophotometry, the determination of $\mathrm{K}$ was performed by flame emission spectrophotometry, $\mathrm{Ca}$ and $\mathrm{Mg}$ through atomic absorption spectrophotometry and $\mathrm{S}$ via turbidimetry. Carbon amounts were obtained by incineration at $1100^{\circ} \mathrm{C}$ with subsequent $\mathrm{CO}_{2}$ determination by NDIR operation principle (Non-Dispersive Infrared).

Soil samples were taken in each sampling unit at $0-5 \mathrm{~cm}$ and $5-10 \mathrm{~cm}$ depth. Samples were dried at $40^{\circ} \mathrm{C}$ and sieved. Chemical analysis were performed on the fine earth fraction $(<2 \mathrm{~mm})$.

Concerning the soil samples, organic carbon content was determined using the Walkey-Black (1934) procedure. Nitrogen was determined after Kjeldahl digestion. The available P was measured colorimetrically after Égneir-Riehm procedure (Balbino, 1968). Concentrations of $\mathrm{K}$ and $\mathrm{Na}$ were analysed by flame emission spectrophotometry. $\mathrm{Ca}$ and $\mathrm{Mg}$ contents were determined using atomic absorption spectrophotometry. Soil $\mathrm{pH}$ was determined with 1:2.5 soil paste and water (McLean, 1982).

An ANOVA was performed to compare the total litter fall among the three study sites. A Tukey test was done for mean multiple comparisons. The same statistical analysis was used to compare the biomass mineral concentrations.

\section{RESULTS AND DISCUSSION}

Total litter fall was $12.44 \mathrm{Mg} \mathrm{ha}^{-1}$ year $^{-1}$ in Padrela, $7.73 \mathrm{Mg} \mathrm{ha}^{-1}$ year $^{-1}$ in Marão and $8.28 \mathrm{Mg} \mathrm{ha}^{-1}$ year ${ }^{-1}$ in Bornes (Fig.1). There were significant differences $(\mathrm{p}<0.05)$ among localities. Padrela stand produced significantly more biomass than the other sites (Table 2) and, consequently, nutrients return to the forest floor was higher than in the 
other sites. The maximum value of carbon sequestration was observed also in Padrela. Leaves are the main component of the litter fall and sequester the largest amount of nutrients and carbon (Table 2). In Padrela, litter fraction is constituted of $50.08 \%$ of leaves, $9.94 \%$ of fruits, $21.09 \%$ of branches and $18.89 \%$ of burs. Litter fraction components in Marão are: $62.29 \%$ of leaves, $5.85 \%$ of fruits, $19.72 \%$ of branches and $12.15 \%$ of burs. In Bornes, litter fraction is composed by $54.36 \%$ of leaves, $3.81 \%$ of fruits, $32.28 \%$ of branches and $9.55 \%$ of burs.

Zimmermann et al. (2002) refer amounts of biomass at Copera similar to those

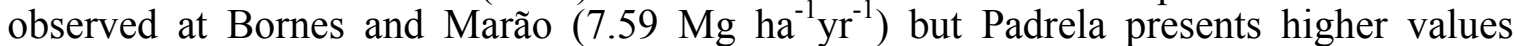
despite the smallest density, due to the deeper and largest dimension of the crowns that produce more leaf litter. The proportions of litter fractions at Copera agree well with our data, except for fruits and branches: $56 \%$ leaves, $18 \%$ fruits, $3 \%$ branches. In our case we found larger amount of branches and smaller amount of fruits than in Copera. The amounts of fruits are difficult to control with this methodology because they are picked up by people and wildlife. Salazar and Santa Regina (2005) reported $5.14 \mathrm{Mg} \mathrm{ha}^{-1}$ year $^{-1}$ as mean annual litter fall for a chestnut coppice stand, located at Sierra de Francia (Spain).

Leaves have the highest concentration of $\mathrm{N}, \mathrm{Mg}, \mathrm{S}$ and $\mathrm{B}$. Branches are the richest in $\mathrm{Ca}$ and fruits in K (Fig. 2). $\mathrm{P}$ is present in high quantities both in leaves and fruits. The nutrients concentrations in total litter fall are significantly different $(p<0.05)$ in the three study sites. Bornes differs significantly from either Padrela and Marão $(p<0.05)$ for the $N$, $\mathrm{Mg}$ and S (Fig. 2). The concentrations of $\mathrm{P}, \mathrm{K}$ and $\mathrm{B}$ are not significantly different among localities $(p<0.05)$. The concentration of $\mathrm{Ca}$ differs between Bornes and Marão. These differences in Ca-concentration in total litter fall can be explained by the different concentrations of exchangeable $\mathrm{Ca}$ in soil. Chatelus (1987) and Leonardi et al. (1996) made similar observations in chestnut coppice. The Mg-concentration in chestnut litter fall is generally lower compared to $\mathrm{Ca}$ and $\mathrm{K}$ and the highest $\mathrm{Mg}$-concentration was found in leaves. According to Marschner (1995), physiologically active parts of plants tend to have higher Mg-concentrations what might explain the highest concentration in leaves.

The available amounts of soil nutrients (Table 3 ) are much higher in the layer 0-5 $\mathrm{cm}$ than in the layer $5-10 \mathrm{~cm}$. The nutrients show a decreasing pattern with soil depth as expected. The amounts of carbon accumulated in the soil are very high compared to the litter.

\section{CONCLUSIONS}

In the three studied chestnut stands, the amounts of returned organic matter and nutrients in litter fall can be explained by several factors such as site conditions (geology, chemistry, microbiology), biogeochemical cycle and also forest age. In the older chestnut stand (Padrela), the total litter return is plenty higher than values reported in literature, but the two other sites they are similar to those found out in older chestnut stands. This can be explained with a deeper and larger crown dimensions. This pattern was observed in a period of two years.

Leaves are the main litter component and the largest amount of nutrients released by the trees was the fallen leaves. The following order, was generally exist $\mathrm{N}>\mathrm{Ca}>\mathrm{Mg}>\mathrm{K}>\mathrm{P}>\mathrm{S}$. The ranking order of the element concentration in fruits was $\mathrm{N}>\mathrm{K}>\mathrm{Mg}>\mathrm{Ca}>\mathrm{P}>\mathrm{S}$. In branches, the amounts of $\mathrm{N}$ and $\mathrm{Ca}$ dominate clearly and the burs are rich in $\mathrm{N}>\mathrm{K}>\mathrm{Ca}>\mathrm{Mg}$. The determined nutrients concentration in litter fall is strongly dependent on the soil nutrient concentration.

\section{ACKNOWLEDGEMENTS}

Research was supported by the AGRO Program, project-267 and FCT, projectPTDC/AGR-CFL/68186/2006. Authors thank to the Forest Services - DGRF. 


\section{Literature Cited}

Balbino, L.R. 1968. O método de Égner-Riehm na determinação do fósforo e potássio assimiláveis em solos de Portugal. Rev. Agron. 51:47-63.

Bourgeois, C., Sevrin, E. and Lemaire, J. 2004. Le châtaignier un arbre, un bois. IDF, 2a Paris.

Chatelus, S. 1987. Contribution à l'analyse du cycle des éléments minéraux dans un écosystème forestier: cas particulier du taillis de châtaignier (Castanea sativa Mill.). Thèse $3^{\mathrm{e}}$ cycle, Université de Limoges.

Duvigneaud, P. 1984. L'écosystème forêt. Ecole nationale de génie rural, des eaux et des forêts, Nancy.

FAO. 1998. World reference base for soil resources. World Soil Resources Reports, Rome, 84.

Kavvadias, V.A., Alifragis, D., Alexandros, T., Brofas, G. and Stamatelos, G. 2001. Litter fall, litter accumulation and litter decomposition rates in four forest ecosystems in northern Greece. For. Ecol. Manage 144: 113-127.

Kerr, G. and Evans, J. 1993. Growing broad leaves for timber. Forestry Commission, London.

Leonardi, S., Santa Regina, I., Rapp, M., Gallego, H.A. and Rico, M. 1996. Biomass, litter fall and nutrient content in Castanea sativa coppice stands of southern Europe. Annu. Sci. For. 53: 1071-1081.

Marschner, H. 1995. Mineral Nutrition of Higher Plants. $2^{\text {nd }}$ Edition, Academic Press, London.

McLean, E. O. 1982. Soil pH and lime requirement. p. 199-224. In: A. C. Page, R. H. Miller, and D. R. Keeney (eds.), Methods of Soil Analysis, Part 2, Agronomy 9. ASA/SSSA, Madison.

Salazar, S. and Santa Regina, I. 2005. Organic matter and nutrient dynamics of the litter layer on a two chestnut stands in Honfria Area, Spain. Acta Hort. 693:691-699.

Walkey, A. and Black, I.A. 1934. An examination of the degtjareff method for determinig soil organic matter and a proposed of the chromic acid titration method. Soil Sci. 37: 29-37.

Zimmermann, S., Braun, S., Conedera, M. and Blasé, P. 2002. Macronutrient inputs by litter fall as opposed to atmospheric deposition in two contrasting chestnut forest stands in southern Switzerland. For. Ecol. Manage. 161: 289-302.

\section{$\underline{\text { Tables }}$}

Table 1. Soil chemical proprieties in $0-10 \mathrm{~cm}$ depth.

\begin{tabular}{llllllllllc}
\hline Locality & Depth & $\mathrm{pH}$ & $\mathrm{P}$ & $\mathrm{N}$ & $\mathrm{K}^{+}$ & $\mathrm{Ca}^{++}$ & $\mathrm{Mg}^{++}$ & $\mathrm{Na}^{+}$ & $\mathrm{B}$ & $\mathrm{C}$ \\
\hline \multirow{4}{*}{ Padrela } & $0-5$ & 4.91 & 16.9 & 29.7 & 0.50 & 3.06 & 2.07 & 0.33 & 2.99 & 20.5 \\
& $5-10$ & 4.55 & 5.1 & 13.2 & 0.28 & 2.03 & 1.27 & 0.34 & 1.19 & 16.7 \\
\multirow{4}{*}{ Marão } & $0-5$ & 3.92 & 30.7 & 21.4 & 0.20 & 1.89 & 1.32 & 0.58 & 3.16 & 34.1 \\
& $5-10$ & 4.02 & 18.2 & 19.9 & 0.09 & 1.49 & 1.13 & 0.24 & 2.00 & 34.1 \\
\multirow{3}{*}{ Bornes } & $0-5$ & 4.65 & 34.8 & 11.1 & 0.24 & 3.29 & 2.63 & 0.25 & 1.75 & 32.7 \\
& $5-10$ & 4.55 & 4.9 & 6.7 & 0.10 & 1.16 & 1.50 & 0.24 & 0.60 & 29.0 \\
\hline
\end{tabular}


Table 2. Biomass and nutrient return to the forest floor from total litter fall (L), biomass components and litter fraction $(\mathrm{F}+\mathrm{H})$, in three old chestnut stands.

\begin{tabular}{|c|c|c|c|c|c|c|c|c|c|c|c|}
\hline \multirow{2}{*}{\multicolumn{2}{|c|}{$\begin{array}{ll}\text { Local. } & \begin{array}{l}\text { Litter } \\
\text { layer }\end{array}\end{array}$}} & \multirow{2}{*}{\multicolumn{2}{|c|}{$\begin{array}{l}\text { Biomass Comp. } \\
\left(\mathrm{Mg} \mathrm{ha}^{-1} \mathrm{yr}^{-1}\right)\end{array}$}} & $\mathrm{N}$ & $\mathrm{P}$ & K & $\mathrm{Ca}$ & $\mathrm{Mg}$ & $\mathrm{S}$ & $\mathrm{B}^{*}$ & $\mathrm{C}$ \\
\hline & & & & \multicolumn{8}{|c|}{$\left(\mathrm{kg} \mathrm{ha}^{-1} \mathrm{yr}^{-1}\right)$} \\
\hline \multirow[t]{6}{*}{ Padrela } & $\mathrm{L}$ & Leaves & 6.23 & 85.79 & 6.30 & 22.17 & 39.59 & 18.66 & 6.21 & 71.28 & 3164.77 \\
\hline & & Fruits & 1.24 & 12.00 & 1.05 & 6.47 & 1.76 & 1.88 & 0.49 & 8.37 & 611.98 \\
\hline & & Branches & 2.62 & 17.80 & 0.74 & 5.70 & 17.52 & 4.24 & 0.72 & 22.12 & 1354.31 \\
\hline & & Burs & 2.35 & 26.00 & 2.32 & 11.30 & 6.10 & 4.33 & 0.99 & 15.24 & 1176.64 \\
\hline & & Total & 12.44 & 141.59 & 10.41 & 45.64 & 64.98 & 29.11 & 8.41 & 117.0 & 6307.71 \\
\hline & $\mathrm{F}+\mathrm{H}$ & & 15.02 & 217.58 & 15.70 & 182.13 & 66.00 & 51.85 & 12.43 & 122.8 & 5035.32 \\
\hline \multirow[t]{6}{*}{ Marão } & $\mathrm{L}$ & Leaves & 4.82 & 63.95 & 3.85 & 6.69 & 18.84 & 13.02 & 2.38 & 62.28 & 2568.84 \\
\hline & & Fruits & 0.45 & 6.13 & 0.55 & 2.66 & 0.38 & 0.83 & 0.21 & 5.06 & 226.81 \\
\hline & & Branches & 1.52 & 9.87 & 0.48 & 1.31 & 7.80 & 2.23 & 0.28 & 12.76 & 812.29 \\
\hline & & Burs & 0.94 & 8.25 & 0.67 & 2.37 & 1.38 & 1.70 & 0.19 & 6.66 & 477.82 \\
\hline & & Total & 7.73 & 88.20 & 5.54 & 13.04 & 28.40 & 17.78 & 3.05 & 86.76 & 4085.75 \\
\hline & $\mathrm{F}+\mathrm{H}$ & $* *$ & & & & & & & & & \\
\hline \multirow[t]{6}{*}{ Bornes } & $\mathrm{L}$ & Leaves & 4.5 & 37.19 & 3.75 & 12.38 & 34.13 & 25.63 & 1.56 & 57.07 & 2379.92 \\
\hline & & Fruits & 0.32 & 2.47 & 0.29 & 1.97 & 0.61 & 0.66 & 0.06 & 2.19 & 155.57 \\
\hline & & Branches & 2.67 & 12.39 & 0.55 & 3.42 & 23.37 & 5.63 & 0.45 & 23.10 & 1405.54 \\
\hline & & Burs & 0.79 & 5.39 & 0.38 & 3.27 & 2.51 & 2.12 & 0.17 & 5.01 & 399.54 \\
\hline & & Total & 8.28 & 57.44 & 4.97 & 21.04 & 60.62 & 34.05 & 2.23 & 87.36 & 4340.57 \\
\hline & $\mathrm{F}+\mathrm{H}$ & & 8.43 & 88.52 & 8.16 & 123.37 & 38.90 & 38.54 & 4.76 & 72.84 & 2661.14 \\
\hline
\end{tabular}

$\mathrm{B},\left(\mathrm{g} \mathrm{ha}^{-1}\right) ; * *$ in this site the abundant grass did not allow to collect the fraction $\mathrm{F}+\mathrm{H}$.

Table 3. Exchangeable cations and other elements of the soil.

\begin{tabular}{llllrrrrrr}
\hline Locality & $\begin{array}{l}\text { Depth } \\
\end{array}$ & \multicolumn{1}{c}{$\mathrm{P}$} & $\mathrm{N}$ & \multicolumn{1}{c}{$\mathrm{K}^{+}$} & $\mathrm{Ca}^{++}$ & $\mathrm{Mg}^{++}$ & $\mathrm{Na}^{+}$ & $\mathrm{B}$ & $\mathrm{C}$ \\
\cline { 2 - 9 } & $(\mathrm{cm})$ & \multicolumn{7}{c}{$\left(\mathrm{kg} \mathrm{ha}^{-1}\right)$} \\
\hline Padrela & $0-5$ & 5.49 & 9642.21 & 63.48 & 199.17 & 82.01 & 24.27 & 0.97 & 66587.63 \\
& $5-10$ & 1.64 & 4212.80 & 35.46 & 129.60 & 49.38 & 24.88 & 0.38 & 53429.87 \\
Marão & $0-5$ & 7.98 & 5562.70 & 20.11 & 98.37 & 41.92 & 34.35 & 0.82 & 88569.87 \\
& $5-10$ & 4.91 & 5380.65 & 9.30 & 80.46 & 37.22 & 14.58 & 0.54 & 92106.90 \\
Bornes & $0-5$ & 9.22 & 2928.25 & 24.80 & 174.10 & 84.97 & 14.92 & 0.46 & 86661.18 \\
& $5-10$ & 1.73 & 2353.17 & 13.88 & 116.08 & 63.91 & 18.90 & 0.21 & 101601.50 \\
\hline
\end{tabular}




\section{Figures}

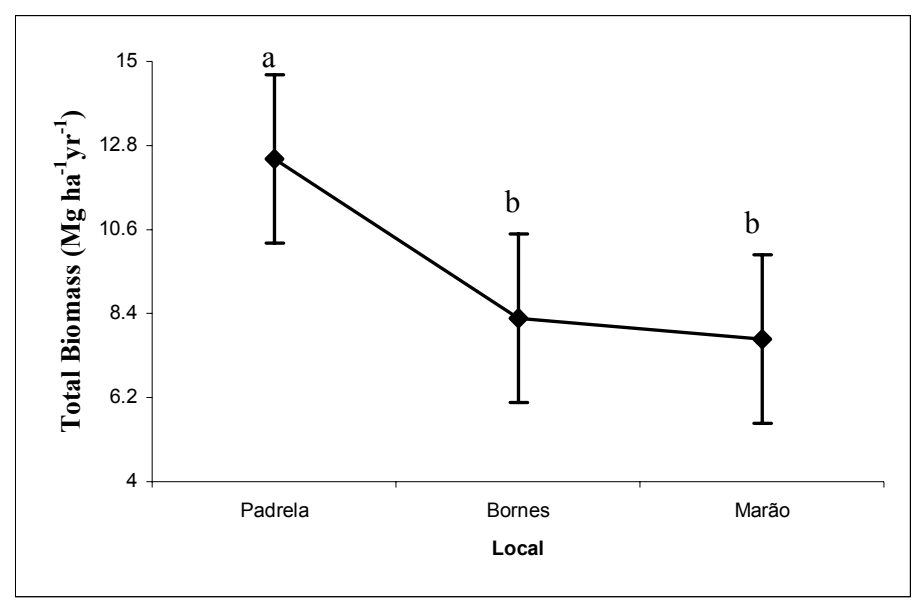

Fig. 1. Total litter fall in the three study sites. Letters indicate significant differences at $\mathrm{p} \leq 0.05$ among means (Tukey test) for total litter fall.

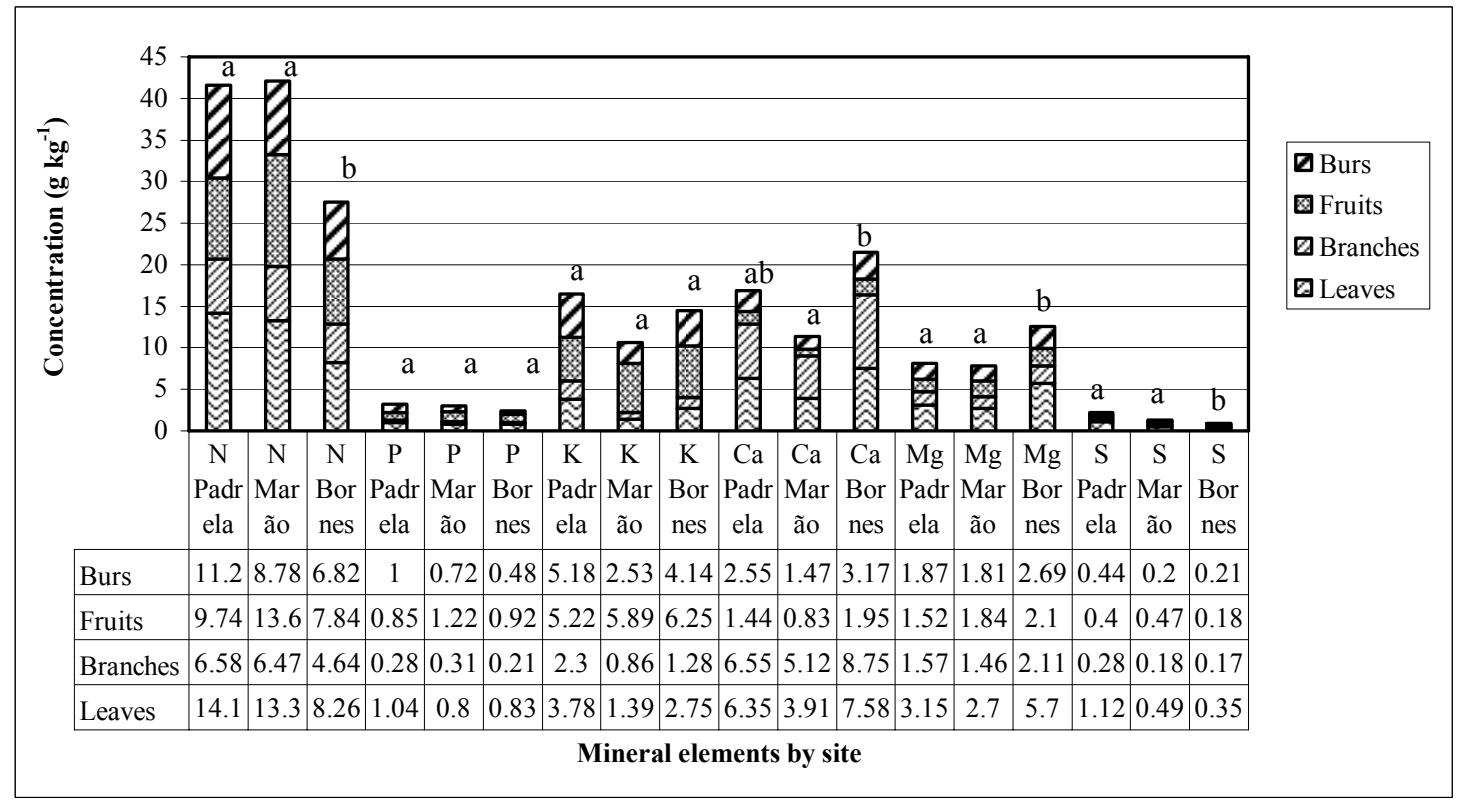

Fig. 2. Nutrients concentration in total litter fall and litter fall fractions by site. Letters indicate significant differences at $p \leq 0.05$ among means (Tukey test) for total litter fall. 